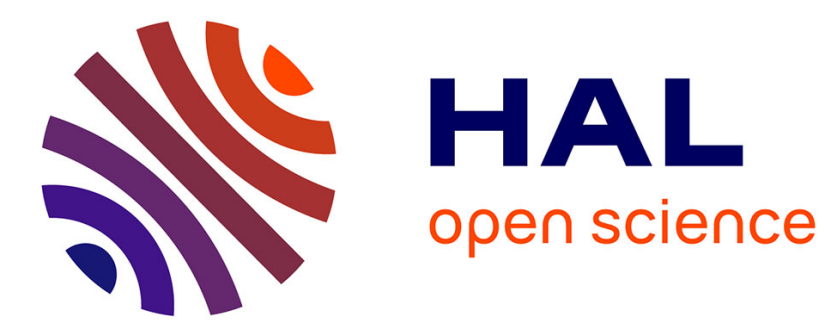

\title{
Long-Term Water Demand Forecasting
}

Jean-Daniel Rinaudo

\section{To cite this version:}

Jean-Daniel Rinaudo. Long-Term Water Demand Forecasting. Understanding and Managing Urban Water in Transition, p 239-268, 2015, 10.1007/978-94-017-9801-3_11 . hal-01183853

\section{HAL Id: hal-01183853 https://hal-brgm.archives-ouvertes.fr/hal-01183853}

Submitted on 11 Aug 2015

HAL is a multi-disciplinary open access archive for the deposit and dissemination of scientific research documents, whether they are published or not. The documents may come from teaching and research institutions in France or abroad, or from public or private research centers.
L'archive ouverte pluridisciplinaire HAL, est destinée au dépôt et à la diffusion de documents scientifiques de niveau recherche, publiés ou non, émanant des établissements d'enseignement et de recherche français ou étrangers, des laboratoires publics ou privés. 


\title{
Chapter 11
}

\section{Long-term water demand forecasting}

\author{
Jean-Daniel Rinaudo \\ Bureau de Recherches Géologiques et Minières (BRGM; French Geological Survey), \\ 1039 rue de Pinville, 34000 Montpellier, France. \\ Email: jd.rinaudo@brgm.fr
}

\begin{abstract}
This chapter reviews existing long term water demand forecasting methodologies. Based on an extensive literature review, it shows that the domain has benefited from contributions by economists, engineers and system modelers, producing a wide range of tools, many of which have been tested and adopted by practitioners. It illustrates, via three detailed case studies in the USA, the UK and Australia, how different tools can be used depending on the regulatory context, the water scarcity level, the geographic scale at which they are deployed and the technical background of water utilities and their consultants. The chapter reviews how practitioners address three main challenges, namely the integration of land use planning with demand forecasting; accounting for climate change; and dealing with forecast uncertainty. It concludes with a discussion of research perspectives in that domain.
\end{abstract}

\section{Introduction}

In the years following World War II, the priority of many governments and water utilities around the world was to develop water supply and increase the percentage of households connected to the mains. Predicting the intermediate- and long-term evolution of the demand for water was thus not a major concern for managers of drinking water utilities. Water was viewed as an inexpensive commodity, and developing excess capacity was considered a much better option than risking a shortage. This tactic worked well - as long as economic and population growth continued and water resources were readily available. This perception gradually changed, however, as the marginal cost of developing new resources progressively rose throughout the 1970s and 1980s, notably in arid regions of developed countries (the western US states, in particular). In other regions, an unanticipated decline in per capita water use led to costly oversized water supply systems. Due to the mounting cost of prediction errors, improving the accuracy of future water demand forecasting became crucial for optimising the expansion of water supply systems. Indeed, building oversized facilities based on an 'upper bound' demand estimate would lead to significant extra cost burdens that would have to be passed on to customers through tariff increases (Beecher and Chesnutt, 2012). Conversely, underestimating future water demand would result in shortages, in this way imposing 
costs in the form of losses in garden landscaping, convenience of water use, and extra constraints on residential and economic development.

Awareness grew that better water demand forecasts meant gaining a better understanding of the factors creating that demand. Early research in the field (Howe and Linaweaver 1967) was quickly followed by the development and diffusion of operational tools and software packages such as IWR-MAIN, released in the 1980s by the US Army Corps of Engineers (Boland, 1997; Bauman et al., 1998). Uninterruptedly for three decades, an abundant flow of scientific literature ensued. This literature can be divided into two main streams. The first comprised contributions from economists who mainly studied the effect of price level and tariff structures on water demand using econometric methods (for a review, see Espey et al. 1997; Arbués et al. 2003; Dalhuisen et al. 2003; Worthington and Hoffman 2008, among others). The second stream consisted of multidisciplinary contributions from civil engineers and modelers (for a review, see Donkor et al. 2012). Both have led to the development of a variety of innovative forecasting tools, based on a variety of modeling techniques (statistical, econometric, neural networks, agent-based models, etc.) and intended to support short-, intermediate-, and long-term forecasting.

Within practitioner communities these tools have become generalised at a pace that has varied from country to country. Overall, a gradual shift from 'water requirement' to 'water demand' models has occurred. Requirement models assume that the amount of water needed per consumer is absolute and constant over time, unaffected by socioeconomic changes. Demand models consider that water use can be altered by pricing and other water conservation policies such as information and awareness-raising campaigns, water device retrofit incentives, etc. This on-going transition, which began in the south-western states of the USA in the 1980s and appeared in the UK at the start of the millennium, has not been adopted in all countries, particularly those where water is still perceived as an abundant resource (for a French example, see Rinaudo, 2013).

A number of books and scientific articles review research in the field (Donkor et al. 2012) or provide technical guidelines on how to implement forecasting methodologies (Billings \& Clive 2008). This literature, however, does not describe how forecasting methodologies have been implemented in practice by water utilities around the world. This chapter presents an attempt at (partially) filling this gap. Based on detailed analyses of three case studies in the USA, the UK, and Australia, it illustrates the diversity of practices, discusses the challenges faced by water utilities, and identifies issues that should be addressed by future research. It is structured as follows: in the next section, we give a brief overview of existing long-term water demand forecasting methodologies. Subsequently, we discuss some of the challenges faced by water utilities when developing water demand forecasts. We then present three case studies illustrating how methods are deployed in operational (as opposed to research) contexts. The chapter concludes by identifying research perspectives to improve forecasting methodologies.

\section{An overview of forecasting methodologies}

\subsection{What is long-term water demand forecasting about?}

This chapter uses the common interpretation of water demand as the observed amount of water consumed by residential, public, commercial, and industrial customers connected to a public water distribution system. Water demand strongly depends on prevailing economic conditions, particularly on water rates and tariffs, population income, and economic activity. Water losses in distribution systems (due to leakage) are not included in demand (Merrett 2004). 
Water demand forecasting can be conducted for varying horizons. Short-term forecasting aims at anticipating water demand over the coming hours, days, or weeks, so as to optimise the operation of water systems (reservoirs, desalination plants) while factoring in changes in weather and consumer behaviors. Short-term demand forecasting can help estimate revenues from water sales and plan short-term expenditures. Intermediate-term forecasting (1-10 years) focuses on the variability of water consumption by a fixed or slowly increasing customer base. It considers changes driven by weather cycles, changes in the composition or characteristics of the customer base, or economic cycles. Long-term forecasting, the focus of this chapter, consider horizons of 20 to 30 years. This is the timeframe taken into account when building long-lifespan water supply infrastructures such as desalination plants, storages, or large-capacity inter-basin transfers. In longterm planning, many factors of change are liable to modify both the customer base and per unit water consumption. Uncertainty is a key issue in long-term water demand forecasting.

Water utilities are not the only players for which such forecasts are a concern. Demand forecasts can be conducted at state or national levels to assess whether, and to what extent, water is likely to become a limiting factor for economic development in the future (see the example of Western Australia below). The result of a forecasting study may determine investment decisions such as the construction of a large regional inter-basin transfer. The level of detail does not require the development of a water forecast for each provider in the state. It may also support decisions concerning water allocation between sectors or regions liable to compete for scarce water resources in the future. Such is the case in Nevada, for instance, where the State Engineer considers the future water demand forecast of a region before authorising export of water to other regions. Here, forecasting serves to protect the interests of rural counties, securing water resources needed for their future development (HRBWA, 2007).

\subsection{A typology of water demand forecasting methodologies}

A variety of models have been developed and implemented by water utilities and their consultants to forecast the future evolution of water demand (Bauman et al. 1998; Billings \& Jones 2008). These models can be classified into five main types (Table 1 ).

Table 1: Main characteristics of water demand forecasting methodologies

\begin{tabular}{|c|c|c|c|c|}
\hline Method & Principle & Applications & Data requirements & Shortcomings \\
\hline $\begin{array}{l}\text { Temporal } \\
\text { extrapolation } \\
\text { models }\end{array}$ & $\begin{array}{l}\text { Projection of past } \\
\text { observed tendencies }\end{array}$ & $\begin{array}{l}\text { Development of a "business } \\
\text { as usual scenario" assuming } \\
\text { a continuation of prevailing } \\
\text { socio-economic conditions }\end{array}$ & $\begin{array}{l}\text { Time series of } \\
\text { water } \\
\text { consumption }\end{array}$ & $\begin{array}{l}\text { Limited predicted } \\
\text { capability - does not } \\
\text { account for changes } \\
\text { in socioeconomic } \\
\text { context }\end{array}$ \\
\hline $\begin{array}{l}\text { Unit water } \\
\text { demand } \\
\text { analysis }\end{array}$ & $\begin{array}{l}\text { Estimation based on } \\
\text { "unit water demand } \\
\text { coefficient" multiplied } \\
\text { by the number of users } \\
\text { in each category }\end{array}$ & $\begin{array}{l}\text { Development of sectoral } \\
\text { demand forecast accounting } \\
\text { for expected future } \\
\text { population growth, change } \\
\text { in economic activity per } \\
\text { branch. Demand can easily } \\
\text { be represented spatially } \\
\text { (link with GIS) }\end{array}$ & $\begin{array}{l}\text { Unit water } \\
\text { consumption } \\
\text { coefficients (per } \\
\text { type of users). } \\
\text { Estimated future } \\
\text { number of users } \\
\text { per category }\end{array}$ & $\begin{array}{l}\text { Does not account for } \\
\text { possible future } \\
\text { changes in unit water } \\
\text { consumption due to } \\
\text { evolving water } \\
\text { tariffs, household } \\
\text { income, etc. }\end{array}$ \\
\hline
\end{tabular}




\begin{tabular}{|c|c|c|c|c|}
\hline $\begin{array}{l}\text { Multivariate } \\
\text { statistical } \\
\text { models }\end{array}$ & $\begin{array}{l}\text { Estimates per capita } \\
\text { consumption as a } \\
\text { function of explanatory } \\
\text { variables such as water } \\
\text { rates, household } \\
\text { income, level of } \\
\text { economic activity } \\
\text { (employment/turnover), } \\
\text { housing characteristics), } \\
\text { weather conditions, etc. }\end{array}$ & $\begin{array}{l}\text { Allows forecasting future } \\
\text { demand considering } \\
\text { changes in (i) population } \\
\text { and economic activity and } \\
\text { (ii) changes in socio- } \\
\text { economic variables (water } \\
\text { rates, households' } \\
\text { characteristics and income, } \\
\text { etc.) }\end{array}$ & $\begin{array}{l}\text { Time series for } \\
\text { water } \\
\text { consumption and } \\
\text { all explanatory } \\
\text { variables. } \\
\text { Estimated future } \\
\text { number of users } \\
\text { per category }\end{array}$ & $\begin{array}{l}\text { Does not account for } \\
\text { changes in plumbing } \\
\text { code or campaigns to } \\
\text { promote water } \\
\text { conservation }\end{array}$ \\
\hline $\begin{array}{l}\text { Micro- } \\
\text { component } \\
\text { modeling }\end{array}$ & $\begin{array}{l}\text { Simulation of end-use } \\
\text { by domestic customers }\end{array}$ & $\begin{array}{l}\text { Demand forecast } \\
\text { considering future changes } \\
\text { in household appliances and } \\
\text { indoor/outdoor water use } \\
\text { practices. } \\
\text { Ex-ante evaluation of the } \\
\text { efficiency of water } \\
\text { conservation policies }\end{array}$ & $\begin{array}{l}\text { Widescale } \\
\text { households survey } \\
\text { to assess } \\
\text { customer } \\
\text { appliance } \\
\text { ownership, } \\
\text { frequency of use, } \\
\text { and volumes used }\end{array}$ & $\begin{array}{l}\text { Mainly adapted to } \\
\text { residential water } \\
\text { demand. Often used } \\
\text { in combination with a } \\
\text { multivariate } \\
\text { statistical model }\end{array}$ \\
\hline $\begin{array}{l}\text { Land use } \\
\text { based } \\
\text { models }\end{array}$ & $\begin{array}{l}\text { Demand assessed on } \\
\text { the scale of uniform } \\
\text { spatial entities using } \\
\text { unit ratio }\end{array}$ & $\begin{array}{l}\text { Spatially accurate water } \\
\text { demand forecast, } \\
\text { integrated with urban } \\
\text { planning }\end{array}$ & $\begin{array}{l}\text { Long range urban } \\
\text { planning scheme. } \\
\text { Unit consumption } \\
\text { ratio per category } \\
\text { of urban } \\
\text { development }\end{array}$ & $\begin{array}{l}\text { Does not account for } \\
\text { changes in economic } \\
\text { conditions (prices, } \\
\text { income) nor } \\
\text { evolution of } \\
\text { technologies/ } \\
\text { plumbing code }\end{array}$ \\
\hline
\end{tabular}

\subsubsection{Temporal extrapolation models}

This modeling approach is based on the assumption that the future evolution of demand can be deduced from past tendencies. Several mathematical models can be used, including moving average, exponential smoothing, or Bow-Jenkins models (Billings and Clive 2008; Donkor et al. 2012). The projection of the tendencies may be applied globally at the scale of a single drinking-water utility or of a region, or be refined by reasoning according to types of consumers (domestic users, services sector, industry). Sophisticated geostatistical methods that simultaneously consider time and space variability have also been used to map future water demand (Lee et al. 2010). The advantage of the extrapolation approach is that the only data required are time series of the variable being forecasted. However, its predictive capability is quite limited because it is unable to take into account changes in the socioeconomic context (tariffs, employment, population and urban patterns) and the occurrence of discontinuities (e.g. changes in technology, plumbing codes, or water conservation policies).

\subsubsection{Models based on 'unit water demand'}

This method typically consists in tying future needs strictly to the number of users. It relies on the use of 'unit water demand' coefficients determined per inhabitant, per customer, per employee, or per unit of industrial output. Demand is estimated by multiplying these coefficients by the number of users the water utility is liable to serve in the future. Applications of the method can be differentiated according to the level of customer disaggregation. The first level of disaggregation generally consists in a breakdown into domestic, commercial, industrial and public-sector uses (sectoral forecasting). Domestic demand may further be decomposed according to housing type, estimating separately multiple dwellings and single-family homes and houses with or without meters. 
Likewise, the demand of industrial and commercial users may be broken down according to activity sector (see the California and UK examples later). One can consider the consumption coefficients as variable with time, extrapolating their future direction from past tendencies. This approach is useful where little or no data are available. It may also suffice when a rough estimate is required for preliminary planning purposes. One of its advantages is transparency, and so it is easily understood by stakeholders. For all these reasons, this method is probably the most commonly used.

\subsubsection{Multivariate statistical models}

This method recognises that change in demand stems from many factors, including water rates and tariffs, household income, climate, economic activity, water conservation programs, etc. The method consists in estimating the statistical relationship between per capita consumption (the dependent variable) and a set of explanatory variables. The main explanatory variables are the cost of water, household income, the level of economic activity (employment or turnover), housing characteristics (proportion of single-family versus collective dwellings, urban density), and possibly weather conditions and the like. The model is generally built using panel data, i.e., a sample of municipalities for which data over a 5-10 year interval is available. Subsequently, the model can be used for prediction purposes to calculate the demand that would be obtained under a hypothetical evolution of the explanatory variables, supposing that the model coefficients (estimated on the basis of a past time window) hold true over the future time window considered. The development of this model type is reflected by an abundant scientific literature (for a review, see Espey et al. 1997; Arbués et al. 2003; Dalhuisen et al. 2003). The main weakness of statistical models for long-range forecasting is their out-of-sample predictive capacity (Fullerton \& Molina 2010).

\subsubsection{Micro-component modeling}

This method, also termed 'end-use modeling', assesses total consumption by simulating in detail the different ways that consumers use drinking water (Froukh 2001). Applied mainly to domestic use, the approach estimates the volumes of water associated with each of the main water use devices: showers, bathtubs, lavatories, sanitary facilities, household appliances (washing machines and dishwashers), kitchen taps, and outdoor devices (hoses and sprinklers, swimming pools). In this model, each use is the product of i) device ownership percentage, ii) frequency of use, and iii) volume per use ${ }^{1}$. In turn, these factors are recognised as capable of being affected by economic prosperity, type of housing, occupancy, climate, and technical developments in waterusing devices. This method's main advantage is that it enables the long-term effect of technological evolution to be simulated: appliance performance, decreased volume of toilet flush, etc. These models are thus more prospective, allowing the effects of water conservation policy incentives to be estimated. The method is widely used by the UK water Industry (see the Thames Water example below) and in the USA (see, for instance, Levin et al. 2006, but examples also come from other countries such as South Africa (Jacobs \& Haarhoff 2004).

\subsubsection{Estimation based on projections for urbanisation and land use}

This method consists in basing the estimated future drinking water demand on urban planning documents and ordinances. The demand forecasting model is integrated into a geographic information system (GIS). Drinking water demand is assessed on a uniform scale of spatial entities (quarters or housing developments for single-family homes, economic activity areas) using unitary

\footnotetext{
${ }^{1}$ Some sophisticated models also account for device leakage (taps dripping or losses due to poor fittings, pipe connections, etc.).
} 
consumption ratios for each type of entity. This method can only be implemented if a relatively detailed urban planning scheme is available, one which is regularly updated and takes into account the target timeframe of the projection exercise.

\subsubsection{Composite models}

In practice, many of the models developed or applied by consultants and/or water utilities are hybrid tools combining several of the methods described above. Note that water planning agencies (such as the UK Environment Agency or the California Bay-Delta Authority) recommend adopting such composite approaches (Davis 2003; Environment Agency et al. 2012). This is also the case for water demand forecasting software packages such as IWR-MAIN, which has been intensively used in the USA (Wurbs 1994; Bauman et al. 1998). IWR-MAIN (standing for Institute for Water Resources - Municipal And Industrial Needs) includes a variety of forecasting models, including extrapolation models, statistical models, unit water demand models, and end-use models. This software has been used by more than 40 large American cities and state organisations (such as the California Water Department), and elsewhere around the world (Mohamed \& Al-Mualla 2010). A number of other hybrid tools have been developed and tested as part of research projects, such as the demand forecasting and management system described in Froukh (2001), but none, to our knowledge, are routinely called on by the water industry.

\section{Key issues and challenges}

Despite significant progress achieved during the last three decades, a number of challenges still have to be addressed by water demand forecasters. Three of these are discussed in the following paragraphs. The first one lies in the need to better integrate water demand forecasting with urban development planning, recognising that uncertainties with new users' water use are intrinsically different than those of existing users. The second challenge consists in improving our understanding of the potential impact of climate change on future demands. The third entails quantifying uncertainties attached to water demand forecasts and developing new procedures to help water managers take robust decisions based on this information.

\subsection{Integrating land use planning and water demand forecasting}

Several statistical studies have pointed out that residential water use is strongly influenced by urban development characteristics, housing density in particular. Per capita water consumption tends to be much higher in urban areas where single-family units (with gardens) represent a large share of the total housing stock. Also, outdoor water use tends to increase with lot size, since larger properties have larger irrigated gardens. A study conducted in Barcelona, Spain, showed that per person water use varied from $120 \mathrm{~L}$ per day in high-density housing to more than $200 \mathrm{~L} / \mathrm{d}$ in lowdensity housing (Domene and Saurí 2006). In the UK, a survey in Yorkshire estimated water use at 370,280 , and $170 \mathrm{~L} / \mathrm{p} / \mathrm{d}$ respectively for detached, semidetached, and terrace houses and flats (Clarke et al. 1997). In California, a study conducted by the Public Policy Institute of California showed that single-family homes use about twice as much landscaping water as multifamily units (Hanak \& Davis 2006). This phenomenon is particularly significant under a dry and hot climate, where outdoor uses related to swimming pools and garden irrigation can represent as much as $50-70 \%$ of total water use, as reported in some states in the western USA (Hanak \& Davis 2006; Wentz \& Gober 2007). Conversely, urban densification may result in decreasing per capita consumption. This tendency is notably reported in Seattle where large single family lots are being converted into new condominiums or smaller town-houses with little or no yard space (Polebitski et al. 2011). A similar 
trend is also observed in large Asian cities where traditional houses are progressively replaced by condominiums (Bradley 2004).

The accuracy of forecasting studies could therefore be enhanced by taking into account the type of urban development to be expected in the future. Analysts should make explicit assumptions about patterns of future dwellings (single- or multiple-family units, flats), average lot size, and characteristics (type of vegetation, percentage of houses equipped with swimming pools, etc.). This can easily be accommodated by existing multivariate regression models, single-coefficient models, or micro-component models (Jacobs \& Haarhoff 2004) if adequate data are introduced. An example is provided by Patterson \& Wentz (2008), who assessed future residential water demand for Phoenix, Arizona, using four urban development scenarios. Scenarios differed according to the statistical distribution of lot size and their spatial distribution. The authors showed that a reduction in average lot size can lead to a $7 \%$ reduction in total water consumption compared to a baseline scenario, assuming a continuation of existing land use patterns (Patterson \& Wentz 2008). A more sophisticated approach in which a water demand model was coupled to an urban simulation model was presented by Polebitski et al. (2011). Model coupling allowed integration into the water demand forecast of assumptions about the position of urban growth boundaries, changes in transportation networks, and new land use policies. The authors showed that certain changes in building characteristics (denser suburban areas) and spatial features of demographic growth lead to demand reductions of about $4 \%$ (over a 20 -year planning period). Urban development modeling can also be fully integrated into the water demand model. An example can be found in (Galán et al. 2009), who use an agent-based model to simulate urban development and water consumption over a 10-year period in the city of Valladolid, Spain.

\subsection{Accounting for climate change}

While a substantial body of literature deals with how climate change impacts water supply, fewer papers have looked at the possible consequences of global warming on long-term urban water demand. Climate change is likely to affect both indoor and outdoor water demands. Indoors, rising temperatures will lead to more frequent showering and more recourse to cooling. Outdoors, higher temperatures, evapotranspiration, and declining rainfall will increase irrigation water needs in gardens and evaporation from swimming pools.

Several methodological approaches have been used to assess this impact on residential water demand. The first entails developing a statistical model that includes weather variables in the explanatory variables. The model can subsequently be used in simulation to predict evolution in water demand while factoring in changes in weather variables. A study conducted in the UK (Goodchild 2003) concludes that, by 2020 , climate change will increase residential water demand by $2 \%$. A similar study conducted in Seattle, WA, showed that climate change could result in a $7 \%$ increase in water demand by 2030 and up to $15 \%$ by the end of the century (Polebitski et al. 2011). ${ }^{2}$ A caveat of the statistical approach is that it assumes people will react to weather variations in the future as they do now, without considering possible changes in water use practices (e.g. allowing lawns to brown in summer or changing landscaping).

A second methodological approach consists in calculating turf irrigation requirements and swimming pool evaporation using climatic and agronomic models. Relying on process-oriented

\footnotetext{
${ }^{2}$ Note that this increase in demand would occur solely in summer months, putting additional stress on water resources and aquatic ecosystems during low-flow periods.
} 
models, the approach is likely to be more robust than the statistical one. It was implemented in southern France by Desprats et al. (2013). Using high-resolution satellite images, the authors quantified the area of irrigated lawns and the presence of swimming pools in a sample of 45,000 detached houses. An agro-climatic model was then used to assess lawn irrigation requirements and swimming pool evaporation under present and future climate conditions. The results showed that residential water demand of single-family homes would increase by $8-10 \%$. All other things equal, this represents a $4-5 \%$ increase in total urban demand (Desprats et al. 2013).

A third approach, implemented in the UK, consists in using a micro-component (or end-uses) model (Downing et al. 2003). Some uses are assumed to be insensitive to climate change. Others, such as shower use, garden watering, and swimming pool refilling, are affected, and the model parameters (use frequency, ownership rate, unit use) are modified accordingly. These changes are based on simple assumptions linking frequency of use with climate parameters such as accumulated degree days (cumulative time being that during which the temperature exceeds a given threshold). The UK study concluded that the impact of climate change will remain modest, ranging between 1 and $1.8 \%$ in 2020 and between 2.7 and $3.7 \%$ in 2050 .

A problem common to the three aforementioned approaches is the uncertainty attaching to climate change scenarios. Different GCMs tend to predict very different changes in temperature, rainfall, and evapotranspiration. The effects of model uncertainties per se are accentuated when different IPCC emission scenarios are adopted. The general conclusion must be that considering climate change in demand forecasting can lead to very different conclusions depending on the chosen climate scenario and the GCM. This was clearly illustrated by Boland (1997) in a case study focusing on Washington, DC, where the impact of climate change on water demand is estimated to range from -4 to $+11 \%$. The most common response to this problem consists in adopting an ensemble approach and considering multi-model average climatic scenarios (Goodchild 2003; Polebitski et al. 2011; Desprats et al. 2013).

An analysis of recent urban water management plans selected from various countries shows that climate change effects on water demand is progressively being taken into consideration in longterm planning. In the UK, most water companies have considered climate change when developing water demand forecasts, albeit in a somewhat simplistic manner. Thames Water, for instance, applied a percentage increase over the 'normal year' forecasts in line with the findings of a national study on "Climate Change and the Demand for Water" (Downing et al. 2003). According to Charlton and Arnell (2011), who reviewed the Water Resources Plans of 21 companies operating in England, most water companies assume an increase in demand ranging between 2 and 5\% (as of 2030). They note that this is minor compared to other drivers of change in demand and the effect of climate change on supply.

In the previous paragraphs, we focused on direct impacts of climate change on water demand. But climate change may also have significant indirect impacts by affecting water demand through structural economic effects. This is nicely illustrated by the water demand forecast study conducted by the State of Western Australia, described in Section 6. Using a macro-economic model, this study assessed the possible impact of global warming on the level of economic activity in the main economic sectors. The indirect impact on water demand was then estimated using a simple 'use coefficient' approach (Thomas 2008). Results showed that this indirect impact far exceeds the direct impact on water use. 


\subsection{Dealing with forecast uncertainty}

Many water consumption prediction models have been developed and used in a deterministic context despite the presence of uncertainty in assumed model structures and parameters. It is now widely recognised that water use forecasts, regardless of the timeframe or the forecast method employed, are likely to be always highly inaccurate (Osborn et al. 1986; Fullerton \& Molina 2010). It is thus crucially important to give consideration to model uncertainties. Two alternative approaches can be called on to do so: the use of contrasted scenarios and the probability approach based on Monte Carlo simulations.

\subsubsection{The scenario approach}

Using a limited number of contrasted scenarios is one way to account for the uncertainty attached to future evolution of water demand. Scenarios consist of a narrative description of ways society might develop and use water in the future. Scenarios are expected to help water utilities assess the performance of alternative strategies under different plausible future conditions. In the UK, this approach was initiated by the Environment Agency in 2001 (Westcott 2004) and further developed since (Environment Agency 2009). The approach was based on more comprehensive scenarios developed for the Environment Agency and Defra to explore pressures on the UK environment and possible changes in them by 2030. Scenarios depict four plausible futures that differ in two main dimensions: first, the type of society (conservationist through to consumerist) and, secondly, the type of governance (growth-focused through to sustainability-focused). Water experts were asked to describe how key factors influencing water demand would be affected by these global scenarios. They defined consistent quantitative assumptions related to water demand drivers which were subsequently used to assess future demand for all resource zones in England and Wales (Environment Agency 2009). Results obtained are illustrated in Figure 1. The result is an envelope within which future water demand is likely to sit. Water companies are then expected to consider these scenarios to identify strategies that perform well under these different plausible representations of the future and to understand the risks inherent in the different alternatives. This approach, however, has been criticised on the grounds of the selection bias for assumption that all forecasters suffer from, based on their own knowledge, beliefs, and ideology. 


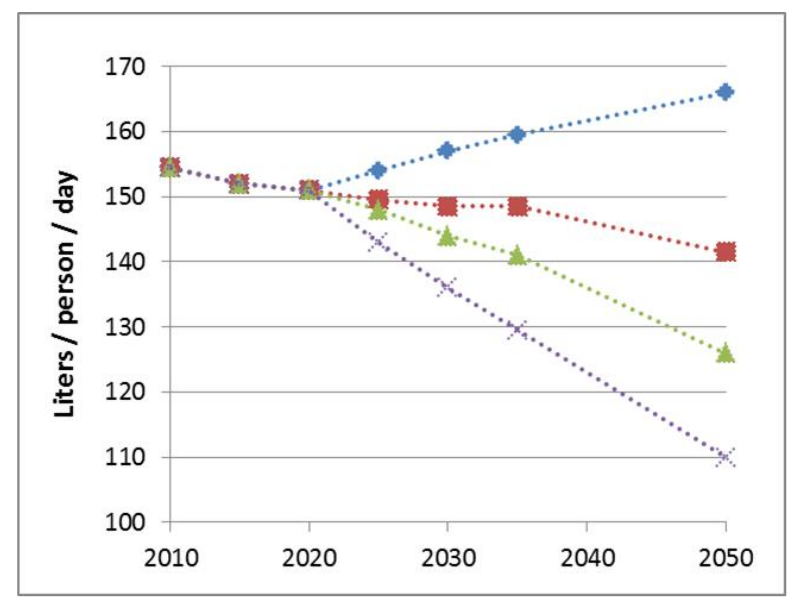

Forecast of per capita consumption

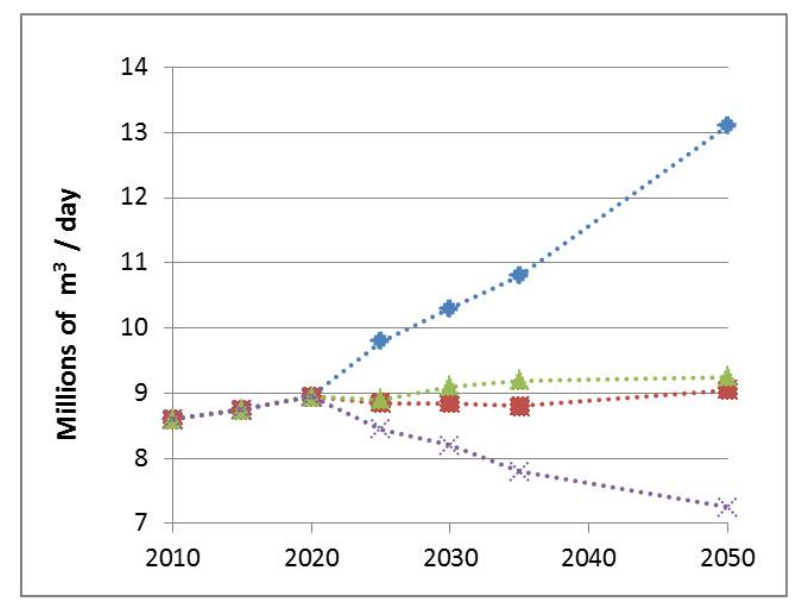

Household demand forecast

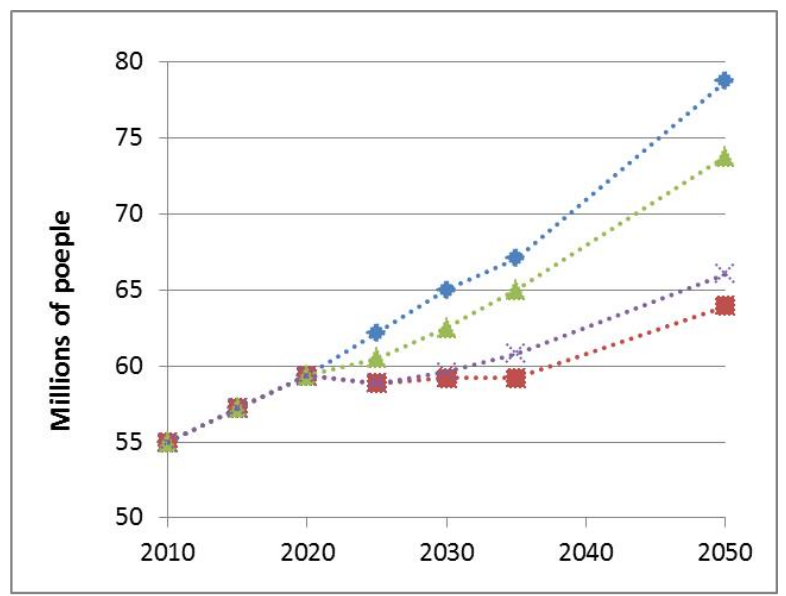

Population forecast

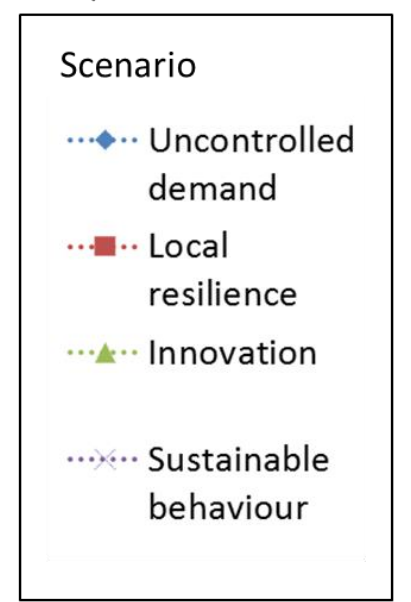

Source: adapted from Environment Agency (2009): pp. 21-24.

Figure 1: Population, per capita consumption, and residential water demand forecasts according to four scenarios.

\subsubsection{The probabilistic approach}

A number of authors criticise forecasts that use only a small number of scenarios, suggesting that uncertainty should really be assessed by considering hundreds of alternative representations of the future. They argue that in situations of great uncertainty, decision-makers need to seek robust rather than optimal (i.e., lowest cost) strategies. Robustness is defined as the ability of a strategy to perform well in a large number of plausible futures (Lampert et al. 2003).

The probabilistic approach consists in running models repeatedly using uncertain input variables randomly chosen from a defined probability distribution. It comprises four steps: i) establish the probability distribution of key factors determining future demand; ii) sample their values based on randomised techniques; iii) calculate water demand for a large number of samples; and iv) compute a statistical distribution of future water demand. The main sources of uncertainty considered are population forecast, economic forecast (employment), water use parameters (end use or total use coefficients) and climate. This approach is now widely implemented by the water 
industry, using software packages such as @RISK (Palisade Corporation) ${ }^{3}$. Applications of this method to the cases of Thames Water (UK) and Tampa Bay Water District (USA) can be found in Thames Water (2010) and Hazen \& Sawyer (2004).

\subsection{Presentation of case studies}

Three case studies are presented to illustrate how the various methodologies are implemented in practice and how the challenges described above have been addressed by practitioners. We deliberately focus on advanced situations. The first example is taken from Southern California, where demand forecasting is conducted at two geographic levels by a regional water importer and retail water utilities. This example describes an interesting combination of econometric and end-use models. The second example, chosen from the UK, illustrates the potential of end-use models. This case study also shows how a very standardised forecasting procedure defined at a national level can be implemented by all water companies. The third and last example was drawn from Western Australia, where water demand forecasting is carried out at the state level. Here, the approach selected strongly relies on a macroeconomic model.

Table 2: Main characteristics of case studies

\begin{tabular}{|c|c|c|}
\hline Location & Forecasting scale & Forecasting method \\
\hline \multirow[t]{2}{*}{$\begin{array}{l}\text { Southern } \\
\text { California, } \\
\text { USA }\end{array}$} & $\begin{array}{l}\text { Regional level } \\
\text { (Metropolitan Water } \\
\text { District of Southern } \\
\text { California) }\end{array}$ & $\begin{array}{l}\text { Statistical multivariate model to forecast per capita consumption } \\
\text { (PCC). Combined with end-use model to assess the effects of water } \\
\text { conservation measures and impact of changing plumbing code } \\
\text { (regional level) }\end{array}$ \\
\hline & $\begin{array}{l}\text { Public utility level } \\
\text { (Eastern Municipal } \\
\text { Water District, } \\
\text { Riverside County, } \\
700000 \text { inhabitants) }\end{array}$ & $\begin{array}{l}\text { Demand forecast mainly based on a spatialized database (GIS) } \\
\text { referencing all potential future residential/commercial constructions/ } \\
\text { developments }\end{array}$ \\
\hline $\begin{array}{l}\text { Thames } \\
\text { Water, UK }\end{array}$ & $\begin{array}{l}\text { Water resource zone } \\
\text { (sub-regional scale, } \\
13.5 \text { million } \\
\text { inhabitants) }\end{array}$ & $\begin{array}{l}\text { Residential demand forecast using a micro-component modeling used } \\
\text { to forecast future PCC values, considering changes in plumbing code, } \\
\text { increase percentage of metered houses, and water efficiency } \\
\text { measures (including water conservation oriented rates). } \\
\text { Non-residential demand forecast using a statistical multivariate model }\end{array}$ \\
\hline $\begin{array}{l}\text { Western } \\
\text { Australia }\end{array}$ & State level & $\begin{array}{l}\text { Multiple water use coefficient model ( } 60 \text { types of users, } 19 \text { regions) } \\
\text { combined with population and economic activity forecast models. } \\
\text { Allows forecasting the impact of macro-economic changes on total } \\
\text { water demand }\end{array}$ \\
\hline
\end{tabular}

\section{Multi-level forecasting in southern California}

\subsection{The context in southern California}

In California, the Urban Water Management Act mandates that each drinking water service shall prepare an urban water management plan, the purpose of which is to ensure a long-term balance between water demand and the resources available and to provide for emergency

\footnotetext{
${ }^{3}$ http://www.palisade.com/
} 
management measures in the event of exceptional drought conditions. These plans, covering a 30 year time span, must be updated every 5 years and submitted to the California Department of Water Resources. They must contain one demand forecast per category of user, including a description of water conservation measures planned by the utility.

In the Los Angeles metropolitan area, this water demand projection is calculated at several geographical levels. At the metropolitan (regional) level, a global demand forecast is established by the water wholesaler, the Metropolitan Water District of Southern California (MWD). MWD imports water from distant sources (Colorado, Northern California, Owens Valley) to supply 26 intermunicipal services (retailers) in the Los Angeles region. MWD's projections are based on a statistical model that seeks to assess the overall needs of the 18 million customers supplied, as well as needs for imported water after the resources available locally have been used up. At a more local scale, each of the 26 retailers does its own projections using methods based on a survey of future development projects. These forecasting tools are described below in greater detail.

\subsection{Demand forecast by the regional importer}

To project the long-term evolution of drinking water demand, MWD calls on a sophisticated forecasting model developed from the IWR-MAIN program, which allows projected population and economic growth to be translated into drinking water demand, while simultaneously integrating the effect of programs to promote water conservation measures. The tool relies on a combination of two types of models (MWD 2010): (i) an econometric (statistical) model that simulates the evolution of consumption ratios; and (ii) a model of end uses that simulates the effect of conservation programs.

The statistical model decomposes the forecast according to types of use (household, commercial, industrial, and public), geographical sector (over 50 sectors at MWD), and season. As to household needs, these are assessed separately in terms of housing type (single-family home, large and small collective dwellings, trailers, rural properties). The model allows the evolution over time of the unitary ratios $\left(\mathrm{m}^{3}\right.$ per capita, $\mathrm{m}^{3}$ per $\mathrm{job}$ ) to be simulated in line with the hypotheses regarding the evolution of household size and revenue, the service rates (price level and structure), the characteristics of new housing (single-family or collective, density), and climate (precipitation). The coefficients of this statistical model were determined by statistical processing (meta-analysis) of the results from 60 case studies carried out in the US. Industrial and commercial needs are assessed by decomposing the demand corresponding to the main branches of economic activities, for which a unitary consumption coefficient $\left(\mathrm{m}^{3}\right.$ per job) is used. This complex statistical model is first used to construct a baseline scenario of total demand considering demographic and economic hypotheses.

A micro-component model is then used to estimate the decrease in demand that can be obtained via water conservation programs. The estimated conserved water is then subtracted from the baseline scenario. The micro-component model decomposes demand into elementary uses such as toilet flushes, washing machines, lavatories and showers, watering gardens, car and floor wash, etc. Hypotheses are made concerning household equipment, how such equipment is used, and leaks (faucets, toilets, garden watering systems). These hypotheses can be adjusted to simulate the effects, at regional scale, of the proactive water-saving policies engaged by MWD, consistent with the policy defined at state level (California Water Conservation Council). An example of these is the distribution of water efficiency kits (shower heads, aerators, low-volume toilet flushers), rebates for the replacement of low-efficiency equipment (US\$100 for washing machines, for instance), conducting consumption audits on private or commercial users with a view to reducing outdoor use, etc. The model also allows the trend effect of the evolution of factory standards (plumbing code) for the equipment being simulated (for example, prohibiting the sale of toilet flushers with a capacity exceeding 6 liters). 


\subsection{Demand projection at the scale of water services}

At a more local level, water retail utilities (municipal water districts) have developed forecasting methods that are more detailed in terms of both their spatial and temporal resolution. The main objective is to make a global assessment of resource needs so as to plan investments in new resources (a plant for desalinisation of brackish groundwater, for example) that can be substituted for water purchased from MWD. Forecasting also aims to determine the spatial distribution of future needs in order to plan for reinforcement or development of the distribution network and storage infrastructure. As the projections are developed in largely the same way by a majority of services, we are presenting here the approach implemented by one of these services, the Eastern Municipal Water District (EMWD).

Located in Riverside County, some $120 \mathrm{~km}$ east of Los Angeles, this service supplies water and sewage treatment to approximately 700,000 inhabitants. Because of the saturation of urban zones nearer Los Angeles, the area has been experiencing vigorous population growth for a number of decades. Growth often exceeded 10\% per year between 1980 and 1990, before leveling off at 3\% per year between 1990 and 2010. It is expected to remain at this level up to 2025. The development of low-density single-family housing generates a strong demand for water due to outdoor uses (gardens and swimming pools). The extremely rapid growth in demand resulting from this necessitates a strong anticipatory ability; otherwise investments made could become poorly suited even before they are amortised. In the worst case, a failure to meet supply needs would entail considerable cost to the local economy.

To assess future needs, EMWD relies on existing prospective studies, which it supplements with its own analyses. To predict the long-term demographic trend at the scale of its territory, EMWD adopts the population growth predictions prepared by the Southern California Association of Governments in the framework of the Transportation Plan. An additional study is then assigned to a specialised consultant, who determines the characteristics and spatial distribution of housing liable to be built to accommodate incoming population to 2030. Changes in the urban environment (types of housing erected) is considered an essential factor in determining future water demand. The study consists of an in-depth analysis of the dynamics of the real estate market, which integrates macroeconomic factors (employment, revenue, credit) as well as more local ones (distance to centers of employment and the attractiveness of the territory, including crime levels, the quality of schools, real estate prices, compared to competing territories).

To complete these projections, EMWD is developing a spatial database (GIS) that allows the potential for building new housing to be estimated from urban planning documents. This base, the Database of Proposed Projects, also makes it possible to identify and follow up on the advancement of all the residential or economic development projects in its territory, from the design phase through to when the meters are installed. In 2005, this database described 150,000 housing units, both single-family and collective, as well as some 10,000 acres of commercial, industrial, or public land (parks, establishments serving the public). This approach makes it possible to anticipate in detail the future demand for water some 2 to 5 years hence. It supplements the other approaches with a more distant timeframe. The approach is updated every 5 years in conjunction with planning conducted at a larger geographic scale by the regional importer, the Metropolitan Water District.

EMWD then takes the population and urban development projections and uses them to calculate future water demand, using per capita consumption coefficients that are adjusted according to the type of housing development (density, lot area, price, average household revenue, etc.), bearing in mind a steady rise in income of its population and a decrease in the number of individuals per household. These ratios are estimated on the basis of a detailed analysis of billing 
databases. Ultimately, demand is estimated for seven categories of users: domestic users in singlefamily, collective housing, commercial customers, industrial customers, public users, institutional users, or green areas and farmland (see Figure 2). EMWD also estimates the water conservation that may be achieved in the future, either passively (improved performance of the water appliances sold) or actively (via programs of specific measures intended to modify practices and behaviors - in particular, the establishment of tariff incentives by increasing tiers). EMWD also regulates new developments requiring water-efficient landscaping. Their Water Use Efficiency Regulations ${ }^{4}$ are similar to other areas that design efficiency into new developments. Future water demand will, by design, differ from the historical one. EMWD's methodology allows this refinement to be included in the forecasts by having the demand from future customers adjusted by municipal or county codes.

EMWD also issues a projection of sales of recycled waste water that it has been developing for specific uses since 2000 as a substitute for drinking water (Figure 3). Globally, the projection method developed by EMWD takes a very large number of factors explicitly into account: demographic and economic growth; the evolution of housing types; the effect of rate changes; the establishment of programs encouraging water conservation; a downward trend in consumption resulting from the evolution in performance of the materials sold; and the development of substitution resources.

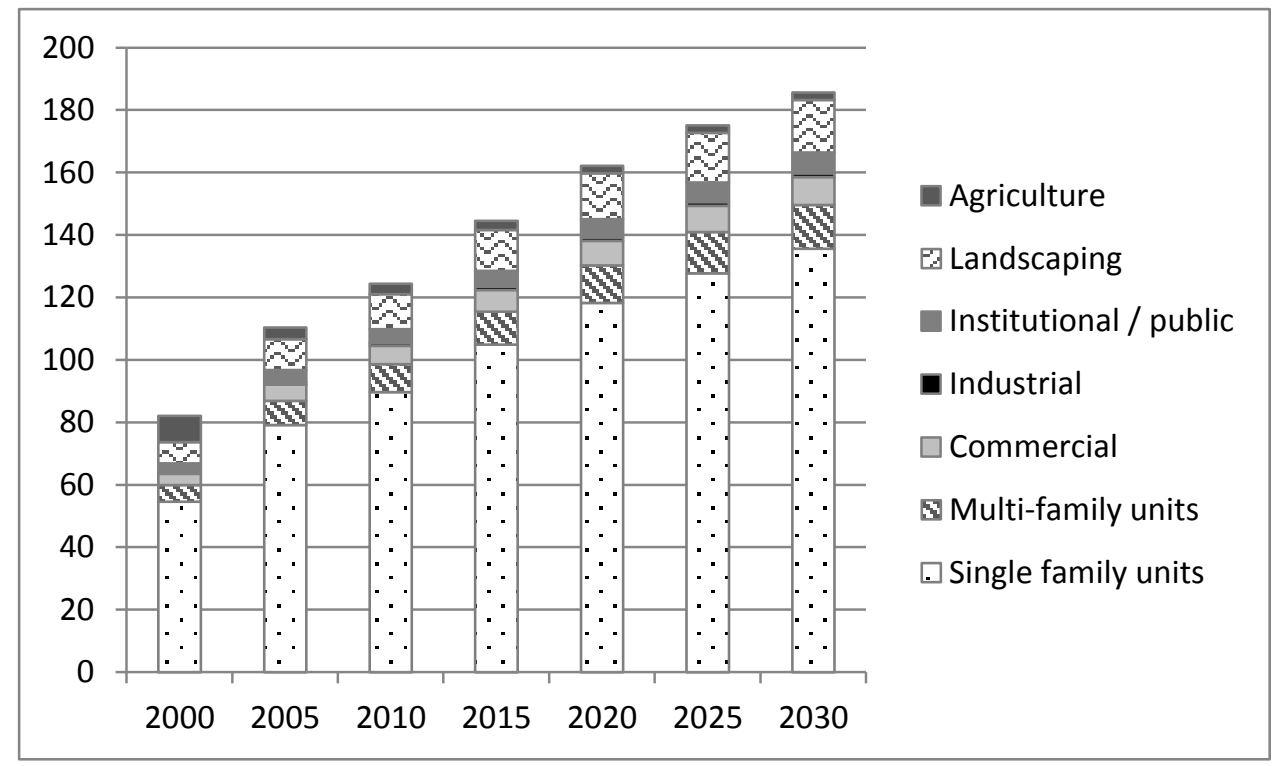

Figure 2: Projection of the evolution in water demand according to user category (millions of $\mathrm{m}^{3}$ per year). Source: adapted from the Eastern Municipal Water District Urban Water Management Plan, 2005.

\footnotetext{
${ }^{4}$ See EMWD Water Use Efficiency Regulation at: http://www.emwd.org/index.aspx?page=91
} 


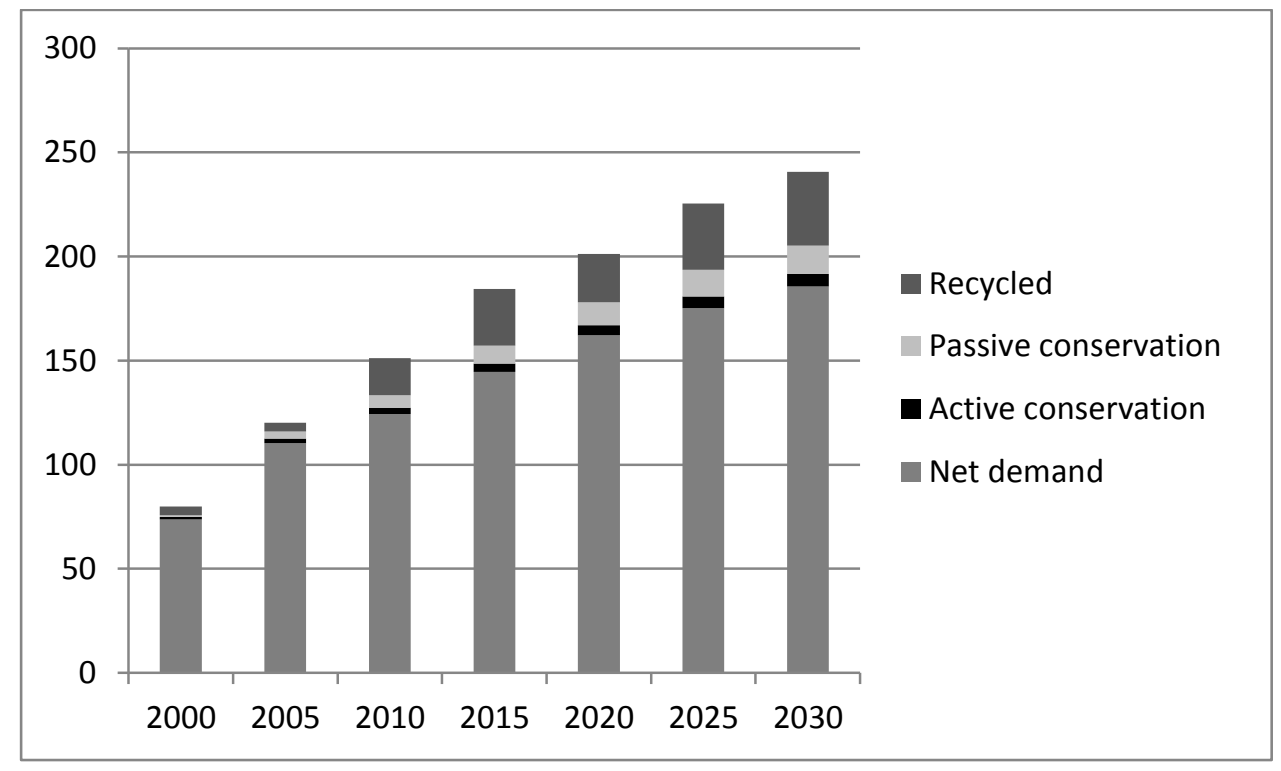

Figure 3: Estimate of expected water savings by the year 2030 (millions of $\mathrm{m}^{3}$ per year). Source: adapted from the Eastern Municipal Water District Urban Water Management Plan, 2005.

\title{
5 The United Kingdom: the micro-component approach
}

\author{
5.1 Regulatory frameworks and national guidelines for demand \\ forecasting
}

In England and Wales, long-run water demand forecasting is mandatory for all water service providers. According to the Water Industry Act of 2003, companies are under the obligation to develop a water resources management plan (WRMP) showing how they propose to balance supply and demand for a 25 -year period. Plans must be revised every 5 years.

The regulators (Ofwat and the Environment Agency) publish and update detailed guidelines specifying the methodology for preparing the plan (Environment Agency et al. 2012). Water companies are required to forecast three main components of demand: household use (metered or not), industrial and commercial use, and leakage.

As to household demand, water companies must use the micro-component modeling approach. This approach makes it possible to estimate how advances in technology, changes in society, and the role of regulation will influence growth or decline in water use over the coming 25 years. This methodology derives from work by Herrington (1995), and has been implemented by the water industry since the mid 1990s (NRA \& UKWIR 1995; UKWIR 1997).

Two types of forecast must be performed. First, a baseline forecast should be established to show how demands are expected to change, assuming existing management and water efficiency policies continue, and considering trends in technology and behavioral change. This forecast aims at identifying potential planning problems (e.g., demand exceeding future available resources). Where a company predicts a deficit in its supply-demand balance, the demand forecast must be revised by incorporating a water conservation program the company proposes to implement over the 25- 
year period. The forecast shall be performed at the resource zone level, which is the fundamental planning unit ${ }^{5}$.

These WRMPs were submitted in 2010 to the regulators by the 23 companies providing water services to domestic, commercial, industrial, and agricultural consumers in England and Wales. The demand forecasting methodology developed by one of these companies, Thames Water, is presented below by way of illustration, based on an analysis of the latest version of their plan (Thames Water 2010).

\subsection{Thames Water forecasting methodology: overview}

Thames Water is the UK's largest water and wastewater services company. It serves 13.5 million customers in London and the Thames Valley, supplying an average of 2.6 million cubic meters of drinking water per day. Household consumption accounts for approximately $50 \%$ of demand, nonhousehold consumption $20 \%$, and unbilled and operational use $2 \%$, while leakage is estimated at $28 \%$ of demand.

The forecasting methodology developed and implemented by Thames Water is based on a modular modeling platform as illustrated in Figure 4. The first module assesses future population and number of households in the water resource zone; the second module estimates present and future residential per capita consumption (baseline scenario); the third module assesses the impact on per capita consumption (PCC) and total demand of policy options (metering program, innovative tariffs); a separate model is developed to forecast non-domestic demand. The modules are integrated at the water resource zone level and run throughout the 25 years of the planning timeframe.

\footnotetext{
${ }^{5} \mathrm{~A}$ resource zone is defined as one where water taken from anywhere within the zone can be supplied to any other location in the zone. There are 68 resource zones in England and Wales. Resource zones are therefore relatively large units compared to what is found in other European countries where water services are still frequently operated at a local (municipal) level (e.g. France).
} 


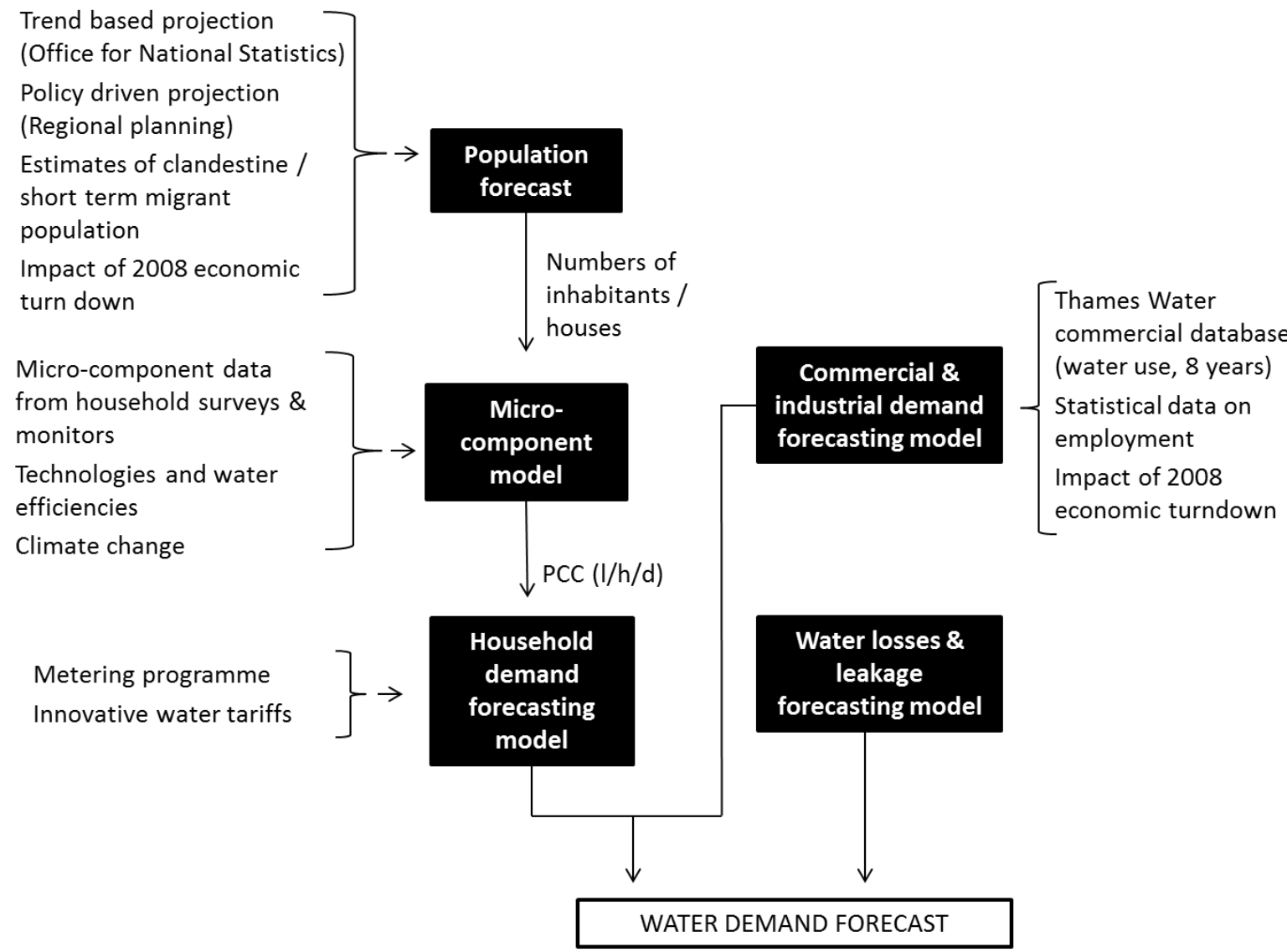

Figure 4: Overview of the demand forecasting methodology implemented by Thames Water.

\subsubsection{Population forecast}

The approach developed by Thames Water to forecast future population is of interest insofar as it combines several methods. The first method reconciles the sub-national trend based population projections developed by the Office for National Statistics (ONS) with policy-driven housing projection defined in the regional plans (regional spatial strategies) ${ }^{6}$. This work, entrusted to a consulting company, led to the definition of a "most likely" population forecast, a forecast subsequently adjusted by including estimated clandestine and short-term migrant populations (estimated to exceed 280,000 persons). Finally, Thames Water commissioned a study to assess the impact of the 2008 economic crisis on employment and population growth. It was assumed that the effects of the crisis would be temporary and that by 2021 recovery would be full, achieving the levels of population and household numbers projected in the most likely scenario. Overall, Thames Water predicts a rise from 8.5 million inhabitants in $2007 / 08$ to 10.2 million by 2034/35, this increase taking place essentially in the London Water Resource Zone (1.3 million).

\footnotetext{
${ }^{6}$ Regional spatial strategies (RSSs) set out how many homes are needed to meet the future needs of the population in the region. They are policy driven and include planned development initiatives by local authorities.
} 


\subsubsection{Per capita consumption modeling and forecasting}

In line with industry best practice, Thames Water has assessed present and future household PCC at the micro-component level, examining the ownership, frequency of use, and volume per use of a range of water-using appliances. Water use per person is influenced by several factors, the main ones being: household occupancy; water consumption of appliances, fixtures and fittings in the property; householders' water use behavior; garden use; and whether the property is metered. The PCC model is calibrated using household data collected through wide-scale surveys carried out every few years $(2003,2007)^{7}$. Additional information procured by monitoring water use in 78 households is also used, as well as results of studies conducted in other regions of England and Wales. Current water use is depicted in Table 3 below.

Table 3: Current water use per micro-component, all water resource zones of Thames Water.

\begin{tabular}{lcc}
\hline Use per micro-component & $\begin{array}{c}\text { Measured } \\
\text { households (\%) }\end{array}$ & $\begin{array}{c}\text { Unmeasured } \\
\text { households (\%) }\end{array}$ \\
\hline Toilet flushing & 22 & 23 \\
Bath use & 12 & 12 \\
Shower & 19 & 10 \\
Clothes washing & 8 & 7 \\
Dish washing & 6 & 5 \\
Garden use & 10 & 8 \\
Miscellaneous use & 21 & 20 \\
Wastage & 2 & 9 \\
\hline
\end{tabular}

Source: Thames Water, 2010.

This model is then run to forecast values of PCC increase over a 30 -year period, assuming changes in future usage based on research and survey data. The main assumptions of the baseline scenario are: replacement of older-model toilets with more efficient ones every 15 years (decrease); increased equipment with power showers (increase); reduction of wastage which is higher for unmetered households than metered ones (9 liters/person/day against $2.6 \mathrm{~L} / \mathrm{p} / \mathrm{d}$ ). Thames Water also considered that domestic consumption would decrease to $125 \mathrm{~L} / \mathrm{p} / \mathrm{d}$ by 2015 in all new properties, following the introduction of new building regulations for fixtures and fittings. The impact of decreasing household size is also considered.

Over the planning period out to 2035, Thames Water assumes an increase in water consumption for showering ( $+24 \%)$ due to more people using showers as opposed to baths $(-8 \%)$, as well as the increasing popularity of power showers. Other micro-components are decreasing, such as dish washing $(-1 \%)$, clothes washing $(-3 \%)$, and toilets $(-10 \%)$ due to improved technology integrated by the manufacturers of these devices. Toilet flush volumes also decrease over the period as water fittings regulations and the increased availability of lower flush volume and dual flush toilets take effect. Overall, short-term reductions resulting from natural replacement of inefficient appliances with newer, more efficient ones are expected to be counterbalanced in the intermediate to long term by an increased ownership of power showers. Climate change is also expected to increase outdoor uses by 4 to $6 \%$ by 2035 (garden watering). PCC is forecast for the 25 years of the planning period; in 2035, it is expected to exceed today's value $(157 \mathrm{~L} / \mathrm{p} / \mathrm{d})$ by $6 \mathrm{~L} / \mathrm{p} / \mathrm{d}$.

\footnotetext{
${ }^{7}$ In 2007, some 60,000 questionnaires were sent out, with 9650 returns.
} 


\subsubsection{Final household demand forecast}

The PCC model outputs are imported into the final household demand model, where additional assumptions can be formulated as to water efficiency policies the company intends to introduce during the 25-year period. The installation of meters is expected to result in a $10 \%$ decrease in PCC, and even up to $20 \%$ if automated meter reading (AMR) equipment is installed, as these can help detect leaks and wastage in individual properties (using devices likes LeakFrog). Another option considered is the introduction of sophisticated tariffs such as increasing block tariffs (IBT) or seasonal/peak tariffs, which are assumed to produce an additional $5 \%$ reduction in demand. Thames Water expects that such tariffs will only be able to be implemented after 2017, when the level of meter penetration has exceeded $50 \%$.

\subsubsection{Non-household demand forecast}

Non-household demand forecast is based on a simple econometric model that establishes a linear statistical relationship between water use and employment. Data used to estimate this model are those in the Thames Water commercial database (measured commercial water deliveries) and statistical information on employment for an 8-year period. Data for industries were pooled into two main groups: service and non-service. For both groups, the elasticity of demand for water with respect to employment is approximately +0.8 . In other words, this means that a 10 percent increase in employment will lead to an 8 percent increase in water demand for water, all else remaining equal. A separate equation is then estimated for 35 main categories of economic activity (classification based on standard industrial classification codes), assuming a +0.8 employment elasticity and estimating a specific intercept value for each activity.

The econometric model was then used to simulate the impact on water demand of economic and employment scenarios, which were prepared by a consultant. Overall, Thames Water expects the downward trend in demand from non-service industries to continue (mainly food, drink, and tobacco industries), falling by almost 25 percent between $2007 / 08$ and 2025/26. This is compensated by an increase in service industries, resulting in a slight increase of industrial water demand.

\subsubsection{Uncertainty assessment}

The uncertainty of the model presented above was assessed by Thames Water consultants using a Monte Carlo approach as described in Section 3. Figure 5 depicts the type of output obtained with this probabilistic approach. It provides an envelope within which future water demand is likely to fit. 


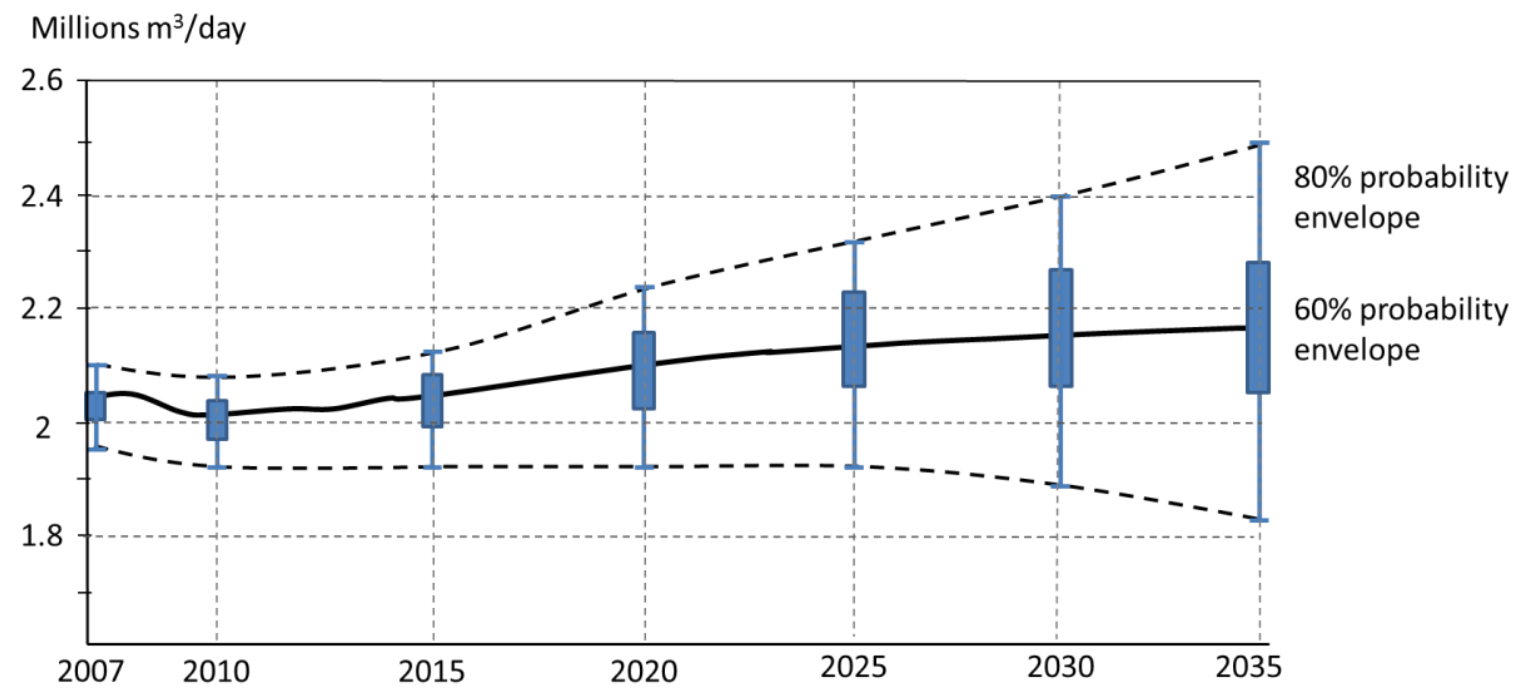

Adapted from Thames Water, 2010, p.96.

Figure 5: Example of uncertainty profile of water demand for London.

\section{State-level forecasting in Western Australia}

Western Australia is the third example we have selected to illustrate current practices in urban water demand forecasting. Here, the forecast is based on a much more global model that estimates water demand for 60 different economic sectors, regardless of where the water they use comes from (self-supplied users or customers of public schemes). This global model was developed by the Department of Water and its results used by water companies such as the Water Corporation of Western Australia, which supplies drinking water to approximately 1.7 million people throughout the state of Western Australia (1.4 million in Perth).

\subsection{Overview of the forecasting approach}

Water demand forecasting is based on the development of a customised modeling tool which was applied to the entire State (Thomas 2008). This model relies on a multiple coefficient approach consisting of: i) estimating water use coefficients for 60 types of users and ii) assessing future evolution of these uses, in terms of population (residential demand) or economic model (added value and employment).

Concerning commercial and industrial uses, water use coefficients (liter/job/day or liter/\$ of added value/day) are estimated for a base year using a licensing database and water companies' customer databases. These are assumed to remain constant throughout the planning period. The projection of added value and employment is based on a large-scale regionalised economic model ${ }^{8}$ which produces three main outputs: the industry added value (sum of wages, salaries, and profits)

\footnotetext{
${ }^{8}$ A dynamic general equilibrium model was used in this case. Water demand forecasting reports, however, do not provide details concerning it.
} 
measured in Australian dollars; industry employment; and total population. All model parameters and predictions are differentiated according to 19 geographical regions.

As to domestic water use, coefficients are adjusted to account for a declining trend in per capita water use. It is assumed that households will manage to reduce water use from a current 290 liter/person/day level (average from 2002 to 2008) to $275 \mathrm{~L} / \mathrm{p} / \mathrm{d} .{ }^{9}$ This represents a simple attempt to anticipate the effects of demand management intervention. However, the model does not allow the specific effect of each alternative water conservation measure to be simulated, as shown in the Thames Water example above.

Once total demand has been estimated for each of the 60 sectors and 19 regions, the model calculates the probable water demand for public schemes in each of the 19 regions. This is based on the assumption that the proportion of total water demand that is met through a scheme supply will remain the same as in 2008 (for each of the 60 sectors). The model does not therefore anticipate possible changes involving substitution of scheme water for self-extracted water or vice versa.

Compared to other modeling approaches presented earlier, the strength of this model resides in two aspects. The first is its ability to link future water demand to anticipated impacts of macro-economic trends on the demand for water ${ }^{10}$. This is a key advantage for forecasting global water demand at the regional level, which is the scale at which the Water Corporation of Western Australia operates. It would, however, be of little relevance for use at the level of small to medium water utilities.

The second strength of the model lies in its ability to assess the proportion of demand met by private sources. This information is often absent in water demand forecasting studies, possibly resulting in an overestimation of demand for scheme water. This is notably the case for residential water demand when the proportion of households equipped with private wells is significant. This applies to Western Australia (see chapter $X$ in this book), where water drawn by households from private wells amounts to half that supplied by public schemes, but also to some European regions where the number of private wells is rapidly increasing (Montginoul \& Rinaudo 2011).

\subsection{Accounting for uncertainty with scenarios}

Projected growth rates for added value, employment, and populations are estimated for several contrasting scenarios to account for uncertainty over future economic development. Four economic and population growth scenarios for future water use have been developed. Note that these scenarios are quite optimistic, given that they were designed prior to the 2008 economic crisis.

The medium growth scenario assumes that the current rate of development of the resourcebased industry continues until around 2014, after which the growth rate declines to historical levels; water use per unit of output is assumed to remain constant. The high-growth scenario assumes that the resource boom continues longer, resulting in a high economic growth rate sustained through to 2030; as in the first scenario, water use per unit of output is assumed to remain constant. The lowgrowth scenario considers a decline in growth rate with stabilisation close to historical levels in 2020; water use per unit of output also remains constant. Finally, a climate change scenario assumes

\footnotetext{
${ }^{9}$ These demand assumptions reflect gains made in water use efficiency over the past 10 years: water use was about $500 \mathrm{~L} / \mathrm{p} / \mathrm{d}$ in 2000/01.

${ }^{10}$ Note however that the model cannot predict the development of totally new activities.
} 
changes in the production pattern at the regional level (decline of agriculture and related industries, increase in forestry, mounting investment in defensive expenditures, particularly in sectors affected by sea-level rise; water use per unit of output increases due to declining rainfall). The range of results obtained is depicted in Figure 6.

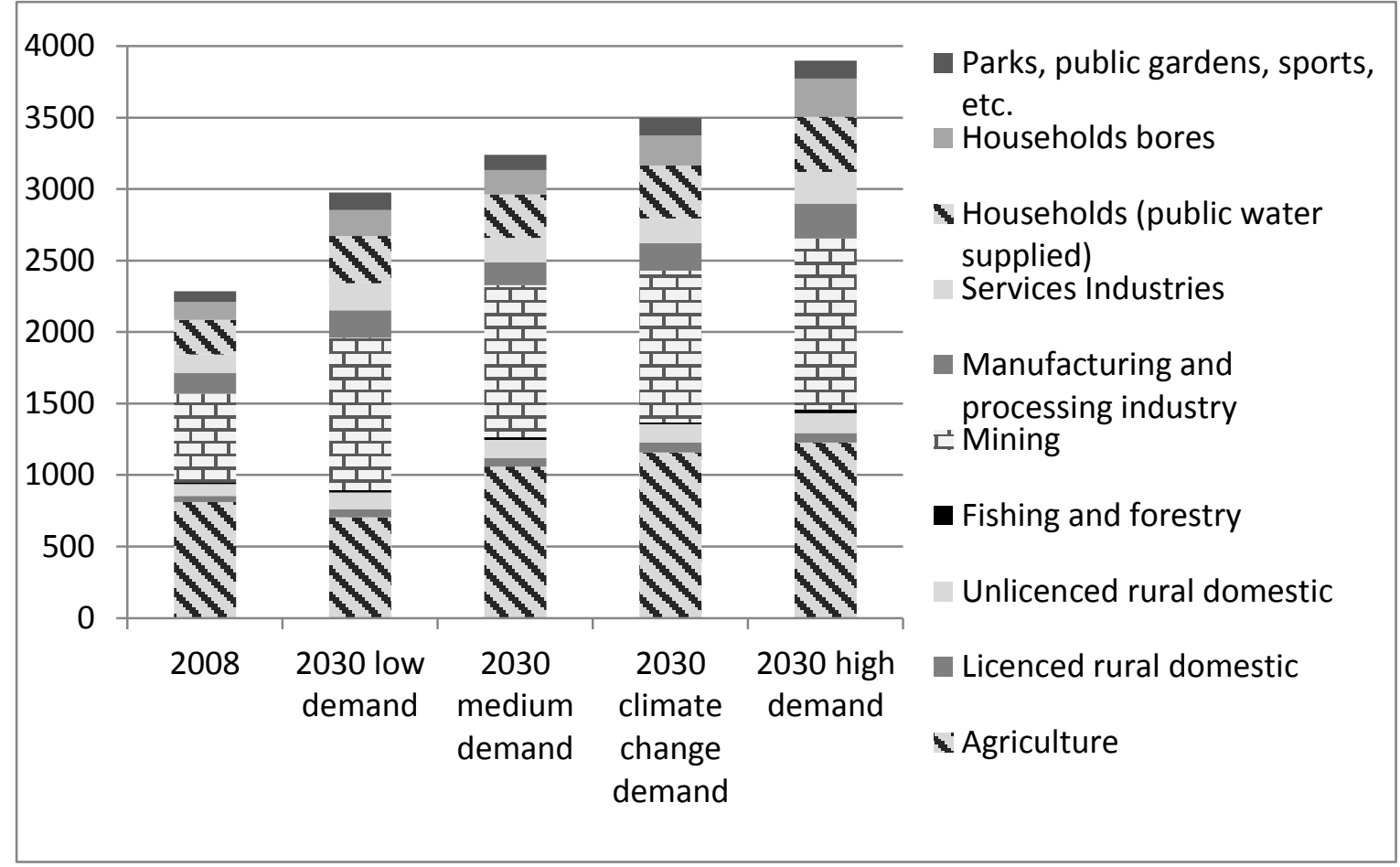

Source: adapted from Thomas (2008)

Figure 6: Total water demand forecast in Western Australia under different macroeconomic and climate scenarios.

\section{Discussion and conclusion}

\subsection{An outlook for the water industry}

The scientific interest for water demand forecasting methodologies was spurred by water supply problems encountered by states in south-western USA during the 1970s and 1980s. Its development has benefited from contributions by economists, engineers, and system modelers, producing a wide range of tools, many of which have been tested and adopted by practitioners. This chapter has illustrated, via three case studies, how forecasting tools can be implemented in practice. The three examples show that there is no single 'off the shelf' forecasting tool that can be applied universally. Different modeling tools can be used depending on the regulatory context, the water scarcity level, the geographic scale at which they are deployed, and the technical background of water utilities and their consultants. For instance, the San Francisco Public Utility Commission used an end-use model, while the Metropolitan Water District of southern California used a customised application of IWR-MAIN, despite the fact that they are in a relatively comparable situation as public water wholesalers. Similarly, the same attention has not been devoted to the impact of climate change in demand forecasts prepared in California, the UK, and Western Australia, this issue being approached using very different methodological perspectives. Uncertainty is also dealt with via very different approaches in our three examples: while not formally assessed in regional water demand 
forecasts in California, it is analysed through Monte Carlo simulations by UK water companies and through a discrete number of contrasted scenarios in Australia. And while land use development planning and water demand forecasting are well integrated in the Eastern Municipal Water District, this issue is given little consideration in the UK and Australia.

Considering climate change and prospects for increased water scarcity in some parts of the world, one might expect that increasing numbers of utilities will have to invest in forecasting activities in the near future. In other areas characterised by declining per capita water use, improved forecasting capacity is needed to avoid costly investment decision errors (Beecher \& Chesnutt 2012). It is likely that composite tools combining econometric models with micro-component models will become a reference in the water industry. Indeed, their strength lies in their ability to simultaneously account for economic changes and water conservation policies, and to allow for an assessment of uncertainty related to population forecast and future climate.

Such tools will not be developed in a uniform manner. Water utilities will only invest in forecasting modeling if the related benefits are clearly perceived. This will mainly happen in areas where the customer base is evolving rapidly, where investment options considered involve large sums of money, and where decisions cannot easily be revised in time. Also, the development will be facilitated where clear methodological guidelines are produced by regulators, as in the UK for instance. This will pave the way for the development of standardised software packages and the emergence of broad-based expertise within consulting companies.

The development of forecasting practices will be facilitated in large utilities, or where public agencies can carry out forecasting studies on their behalf (see the case of Nevada, for instance). Indeed, developing, calibrating, and regularly updating water demand forecasting models requires significant financial and technical capacities that many utilities around the world are not able to mobilise. For instance, the forecasting study conducted by the San Francisco Public Utility Commission (supplying a population of 2.4 million) mobilised over 100 persons working on the project for 2 years (Levin et al. 2006).

Similarly, certain types of models require detailed data that are difficult or costly to acquire by any single utility. For instance, end-use models require conducting large-scale household surveys (or monitors) to estimate appliance ownership rates, use frequency, and average use per load. Such models are likely to be more easily adopted if governments or the water industry produce generic information that can be used by water utilities. Institutions like the Research Foundation of the American Water Works Association and the UK Water Industry Research have played a key role in that respect, which can explain the widespread use of complex models in these two countries.

\subsection{Research perspectives}

Most of the models described in this chapter also suffer from the same serious weakness, namely that their structures and parameters rely on statistical evidence derived from past observations. In the context of rapid technological, climatic, economic, and societal changes, some authors argue that the predictive power of these methods may be rather limited (Galán et al. 2009). They insist on the need to develop models that capture the underlying causal relations determining the evolution of water demand under changing structural conditions. This implies explicitly modeling how users (households in particular) take decisions concerning water use practices, the purchase of appliances, and investment in alternative water supply sources such as rainwater harvesting systems, in-house grey-water recycling, or the drilling of private wells. 
Research is presently on-going in that field, using different approaches. Rosenberg et al. (2007) have modeled household water use by explicitly describing multiple sources that can be used at different prices and with different water qualities suited to specific uses. Their model then looks for the least cost combination of actions that allows a household's water needs to be satisfied in a stochastic environment. They show how this can help quantify demands for indoor and outdoor uses and how customers may respond to water conservation incentives embedded in a tariff structure. Micro-economic models have also been used to simulate a household's water supply decision, assuming that users are trying to minimise the cost of water supply through an optimal combination of water sources. This approach was implemented in France, for instance, to simulate how households decide to drill wells and use cheap untreated groundwater as a substitute for tap water (Montginoul \& Rinaudo 2011).

Social modelers adopt a much broader perspective by explicitly taking into account social phenomena that affect water demand, and the interaction between them. As compared to microeconomic approaches, they attempt to describe intra-population dynamics. This is mostly done through the development of agent-based models (ABMs) that aim to simulate the functioning of a society based on a detailed representation of individual agents' decisions and the interactions between them. Water demand ABMs can simulate households' decisions in terms of technology change (diffusion of innovation), compliance with regulations (irrigation bans), and volume use per load or per activity (showers). One of the main features of ABMs is their assumption that households are community-oriented agents, meaning that their decisions and actions are strongly influenced by the community around them, their neighborhood, and their social environment (Athanasiadis et al., 2005). For instance, households may agree to voluntarily reduce water use during droughts, but they may quickly shift back to their initial practices if they realise that most of the community is making no effort. Another key feature consists in assuming heterogeneity of agent characteristics and behavioral motivations, resulting in a greater diversity of responses to regulatory and economic policy signals and incentives. For instance, Athanasiadis et al. (2005) consider three main types of consumers: i) households sensitive to water conservation objectives, who are directly impacted by information campaigns and actively promote the diffusion of innovative practices in their social networks (opinion leaders); ii) households indifferent to public awareness campaigns and insensitive to social issues, who will have a negative attitude towards conservation; and iii) households who act as opinion followers and who will engage in conservation as a result of their interactions with opinion leaders. ABMs can be combined with other models. In the DAWN model developed by Athanasiadis et al. (2005), for instance, an econometric model is nested within an ABM; the econometric model is used by agents to calculate their baseline water consumption before agents take decisions related to water conservation activities based on social interactions with their neighbors. This modeling approach has only been used in a limited number of research studies in the UK (Bartélémy 2008), Greece (Athanasiadis et al. 2005), and Spain (López-Paredes et al. 2005; Galán et al. 2009). To our knowledge, it has not been used as a planning tool by water utilities, but rather as tools to "aid in advancing our knowledge about the complex dynamic of the whole water management system" (Galán et al. 2009). Integrating such models with existing tools and promoting operational applications and deployment by water utilities represents a real challenge which, we believe, should be taken up by researchers.

\section{Acknowledgments}

This chapter was prepared as part of the Eau\&3E project funded by the French Research Agency (ANR), grant VD-08-321989. I warmly thank Antony Pack, Chairman of EMWD, and Tim Brick, chairman of Metropolitan Water District, as well as their staff for sharing their invaluable experience 
during a visit to California in September 2010. I also express my appreciation for comments made by Bernard Barraqué and Tom Chesnutt on an earlier version of this paper. The usual disclaimers apply.

\section{References}

Arbués, F., Garcia-Valinas, M. A. \& Martinez-Espiñeira, R. (2003). Estimation of residential water demand: a state-of-the-art review. Journal of Socio-Economics, 32, 81-102.

Athanasiadis, I. N., Mentes, A. K., Mitkas, P. A. \& Mylopoulos, Y. A. (2005). A hybrid agent-based model for estimating residential water demand. Simulation, 81, 175-187.

Bartélémy, O. (2008). Scenarios for water demand forecast. In: A. Lopez Paredes. a. C. Hernandez Iglesias (Ed.), Agent based modelling in natural resource management. Valladolid, Spain: INSISOC.

Bauman, D. D., Boland, J. J. \& Haneman, W. M. (1998). Urban water demand management and planning. New York: McGraw-Hill.

Beecher, J. A. \& Chesnutt, T. W. (2012). Declining sales and utility revenues: a framework for understanding and adapting. Alliance for Water Efficiency, white paper for National Water Rates Summit, Racine, Wisconsin.

Billings, R. B. \& Jones, C. V. (2008). Forecasting urban water demand. Denver, CO: American Water Works Association.

Boland, J. (1997). Assessing urban water use and the role of water conservation measures under climate uncertainty. Climatic Change, 37, 157-176.

Bradley, R. (2004). Forecasting domestic water use in rapidly urbanizing areas in Asia. Journal of Environmental Engineering, 130, 465-471.

Charlton, M. B. \& Arnell, N. W. (2011). Adapting to climate change impacts on water resources in England: an assessment of draft water resources management plans. Global Environmental Change, $21,238-248$.

Clarke, G. P., Kashti, A., McDonald, A. \& Williamson, P. (1997). Estimating small area demand for water: a new methodology. Journal of the Chartered Institute of Water and Environmental Management, 11, 186-192.

Dalhuisen, J. M., Florax, R. J. G. M., De Groot, H. L. F. \& Nikamp, P. (2003). Price and income elasticities of residential water demand: a meta analysis. Land Economics, 79(2), 292 - 308.

Davis, W. Y. (2003). Water demand forecast methodology for California water planning areas: work plan and model review. Sacramento, CA: California Bay-Delta Authority.

Desprats, J., Rinaudo, J.-D. \& Montginoul, M. (2013). Controlling residential water demand through urban planning: lessons learnt from two French case studies. Proceedings, 3rd International IWA Conference on Water Economics, Statistics and Finance, Marbella, Spain. London: International Water Association.

Domene, E. \& Saurí, D. (2006). Urbanisation and water consumption: influencing factors in the metropolitan region of Barcelona. Urban Studies, 43, 1605-1623. 
Donkor, E., Mazzuchi, T. A., Soyer, R. \& Roberson, J. A. (2012). Urban water demand forecasting: a review of methods and models. Journal of Water Resources Planning and Management, 10.1061/(ASCE)WR.1943-5452.0000314.

Downing, T. E., Butterfield, R. E., Edmonds, B., Knox, J. W., Moss, S., Piper, B. S. \& Weatherhead, E. K. (2003). Climate change and the demand for water. Oxford, UK: Stockholm Environment Institute.

Environment Agency (2009). Water for people and the environment: Water resources strategy for England and Wales. Bristol, UK.

Environment Agency, Ofwat, Defra \& Welsh Government (2012). Water resources planning guideline: the technical methods and instructions, $187 \mathrm{pp}$. Online at http://cdn.environmentagency.gov.uk/geho0612bwpe-e-e.pdf, accessed 11 November 2013.

Espey, M., Espey, J. \& Shaw, W. D. (1997). Price elasticity of residential demand for water: a metaanalysis. Water Resources Research, 33, 1369-1374.

Froukh, M. L. (2001). Decision-support system for domestic water demand forecasting and management. Water Resources Management, 15, 363-382.

Fullerton, T. M. \& Molina, A. L. (2010). Municipal water consumption forecast accuracy. Water Resources Research, 46, W06515.

Galán, J. M., López-Paredes, A. \& del Olmo, R. (2009). An agent-based model for domestic water management in Valladolid metropolitan area. Water Resources Research, 45, W05401.

Goodchild, C. W. (2003). Modelling the impact of climate change on domestic water demand. Water and Environment Journal, 17, 8-12.

Hanak, E. \& Davis, M. (2006). Lawns and water demand in California. California Economic Policy, 2(2).

Hazen and Sawyer (2004). The Tampa Bay Water long-term demand forecasting model. Tampa, FL: Tampa Bay Water.

Herrington, P. (1995). Climate change and the demand for water. London: Institute of Hydrology and the Department of the Environment.

Howe, C. W. \& Linaweaver, F. P. (1967). The impact of price on residential water demand and its relationship to system design and price structure. Water Resources Research, 3, 13-32.

HRBWA (2007). Forecasting water demans in the Humboldt basin: capabilities and constraints. Carson City, NV: Humboldt River Basin Water Authority.

Jacobs, H. E. \& Haarhoff, J. (2004). Application of a residential end-use model for estimating cold and hot water demand, wastewater flow and salinity. Water SA, 30, 305-316.

Lampert, R. J., Popper, S. W. \& Bankes, S. C. (2003). Shaping the next one hundred years: new methods for quantitative long term policy analysis. Santa Monica, CA: RAND Corporation.

Lee, S.-J., Wentz, E. \& Gober, P. (2010). Space-time forecasting using soft geostatistics: a case study in forecasting municipal water demand for Phoenix, Arizona. Stochastic Environmental Research and Risk Assessment, 24, 283-295. 
Levin, E., Maddaus, W. O., Sandkulla, N. M. \& Pohl, H. (2006). Forecasting wholesale demand and conservation savings. Journal of the American Water Works Association, 98, 102-111.

López-Paredes, A., Saurí, D. \& Galán, J. M. (2005). Urban water management with artificial societies of agents: the FIRMABAR simulator. Simulation, 81, 189-199.

Merrett, S. (2004). The demand for water: four interpretations. Water International, 29, 27-29.

Mohamed, M. \& Al-Mualla, A. (2010). Water demand forecasting in Umm Al-Quwain (UAE) using the IWR-MAIN Specify Forecasting Model. Water Resources Management, 24, 4093-4120.

Montginoul, M. \& Rinaudo, J.-D. (2011). Controlling households' drilling fever in France: an economic modeling approach. Ecological Economics, 71, 140-150.

MWD (2010). The regional urban water management plan. Metropolitan Water District of Southern California, Los Angeles, 407 pp.

NRA \& UKWIR (1995). Demand forecasting methodology: main report. 95/WR/01/1. ISBN 184057 1209

Osborn, C. T., Schefter, J. E. \& Shabman, L., 1986. The accuracy of water use forecast: evaluation and implications. Journal of the American Water Resources Association, 22, 101-109.

Patterson, J. \& Wentz, A. E. (2008). Forecasting single-family residential water consumption for Phoenix and Paradise Valley, Arizona. Phoenix, AZ: Arizona State University, geoDa Center.

Polebitski, A., Palmer, R. \& Waddell, P. (2011). Evaluating water demands under climate change and transitions in the urban environment. Journal of Water Resources Planning and Management, 137, 249-257.

Rinaudo, J.-D., (2013). Prévoir la demande en eau potable: une comparaison des méthodes utilisées en France et en Californie. Eau, Agriculture et Territoires 10, 78-85.

Rosenberg, D. E., Tarawneh, T., Abdel-Khaleq, R. \& Lund, J.R. (2007). Modeling integrated water user decisions in intermittent supply systems. Water Resources Research, 43, W07425.

Thames Water (2010). Planning for the Future: revised draft water resources management plan.

Thomas, J. F. (2008). Water futures for Western Australia 2008-2030. Volume 1: State Report. Perth, W.A.: Resource Economics Unit, Department of Water, 67 pp.

UKWIR (1997). Forecasting water demand components: best practice manual.

Wentz, E. \& Gober, P. (2007). Determinants of small-area waterc for the city of Phoenix, Arizona. Water Resources Management, 21, 1849-1863.

Westcott, R. (2004). A scenario approach to demand forecasting. Water Science \& Technology, 4, 4555.

Worthington, A. C. \& Hoffman, M. (2008). An empirical survey of residential water demand modelling. Journal of Economic Surveys, 22, 842-871. 
Published in in : Understanding and managing urban water in transition. Edited by: Grafton Q., Daniell K.A., Nauges C, Rinaudo J-D. \& Wai Wah Chan N. (2015) Springer.

Wurbs, R. A. (1994). Computer models for water resources planning and management. Alexandria, VA: US Army Corps of Engineers. 